\author{
https://doi.org/10.52449/1857-4114.2020.35-1.13
}

CZU: 796.015:796.8

\title{
ESTIMATION OF FUNCTIONAL AND PHYSICAL TRAINING OF WRESTLERS WITH THE USE OF INTERVALOMETRY AND LOADS OF SUBMXIMAL AND MAXIMUM INTENSITY
}

\author{
Manolachi Victor ${ }^{1}$, ORCID: 0000-0002-3904-3564 \\ Manolachi Veaceslav ${ }^{2}$, ORCID: 0000-0001-8744-6125 \\ Mrut Ivan ${ }^{3}$, ORCID: 0000-0002-1344-9945 \\ Postolachi Alexei ${ }^{4}$, ORCID: 0000-0002-6760-9174 \\ ${ }^{1,2,3,4}$ State University of Physical Education and Sport, Chisinau, Republic of Moldova
}

\begin{abstract}
The methodology for determining the indicators of special physical and functional readiness of wrestlers, proposed by the authors, is distinguished by its simplicity and, at the same time, originality. The presence of a large number of discrete values makes the proposed method for determining indicators more sensitive and allows more accurate assessment of the results of maximum tests using loads of a specific nature of maximum and submaximal power, standard dosed load of a specific nature of submaximal power. It makes it possible to more accurately determine the degree of influence on the body of wrestlers of various qualifications, weight category and gender, the body's response to a specific load: heart rate, respiratory rate after exercise and the speed of recovery processes, indicators of physical performance and maximum oxygen consumption, as well as to carry out a comparative analysis efforts of wrestlers when performing physical activity of a specific nature of maximum and submaximum power. The data given by the authors allow to more effectively carry out operational and staged control over the process of training wrestlers of various styles, to make timely adjustments to the training plans of athletes

Keywords: impulse measurement, intervalometry, discrete values, maximum test, physical activity, physical and functional training.
\end{abstract}

Actuality. The progress of science requires an increase in the methodological level of research. This is achieved through not only the introduction of new complex technology, but also a more rational use of existing, including simple, publicly available methods. The maximum test is one of the most widespread and informative methods in the practice of sports physiology, sports medicine and pedagogy $[1,7,8,9]$. At the same time, increasing the accuracy of research, metrological substantiation of the choice of more reliable methods of obtaining information are of particular importance and, in this regard, the advantages of intervalometry force us to raise the question of the preference of such a named method $[9,11$, 12]. The simplicity and accessibility of the method fully justifies its popularity. In this regard, the metrological substantiation of the assessment of test results, which, being a method of quantitative research, must have the required level of accuracy, that is of great importance. In scientific works it is used instrumental methods of recording test results in 30 or 60 seconds with its subsequent analysis, the researcher easily obtains the required degree of accuracy $[5,6,8]$. All of the above confirms the actuality of our research. 
The purpose of our research. To improve the system of training wrestlers at various stages of sports training.

Research objectives. To achieve this goal, the following tasks were solved:

1. To study the methodology of control over the level of special physical and functional training of wrestlers at different stages of sports training.

2. To determine the dynamics of physical and functional training of wrestlers, as well as metrological features of the use of tests with the use of motor tasks of a specific nature and intervalometry.

\section{Research methods:}

- analysis of scientific and methodological literature;

- pedagogical observations of the educational and training process and competitive activity of wrestlers of various styles;

- research of morphological and functional indicators of wrestlers of various styles;

- mathematical and statistical methods of data processing.

Research results. Physiological reactions to physical activity, as well as the mechanisms that determine the functional capabilities of the body and their change under the influence of sports training, do not fundamentally differ in women and men. When comparing functional indicators in women and men, one should, first of all, take into account the differences in body size (height, weight), which in itself predetermines gender differences in physical performance indicators, which are associated with specific functional differences in the body of women and men [6, 7, 10]. The work performed with a certain power must be provided with an equivalent supply of chemical energy (oxygen) to the working muscles. Consequently, energy consumption the rate of oxygen consumption (O2) is associated with the mass of working muscles and body weight. From theoretical premises, it should be expected that it is the differences in body size (body weight and muscle mass) that primarily explain the higher values of physical (strength, speed, endurance) and functional (heart rate at rest and after a standard dosage load, physical performance ( $\mathrm{PWCl70)}$ ) and maximum oxygen consumption (MOC)) fitness of men compared to women. This is especially pronounced when determining the results of the maximum test using physical loads of a specific nature of various power the execution of dummy throws $[3,4,9,10$, $11,13]$.

The results of the maximum test can be assessed using two methods: impulse measurement (recording the number of repetitions of a test task for a certain period of time) and intervalometry - recording the duration of a certain number of repetitions of a test task $[1,2,11,12]$.

Operative impulse measurement in sports practice is characterized by two features.

Firstly, due to the high dynamics of the throwing cycles, clearly tracking changing load levels, it is necessary to carry out in short periods of time. It is common to count the number of repetitions "to failure" in 15,30 or 60 seconds.

Secondly, operational ipulsometry (the number of shots over a certain period of time) is carried out organoleptically (visually, palpation or by ear) and by a stopwatch.

But even where instrumental research is carried out, intervalometry is of great importance, because, on the one hand, it ensures the urgency of obtaining information, and on the other hand, it allows you to control the readings of more complex devices, the reliability and accuracy of which will be inferior to those of a working chronometer for a long time.

It should be recalled that the accuracy of this simple device is about $0.1 \%$ (after all, if it sins for 1 minute per day, it is even less than $0.1 \%)$.

In connection with the above, the metrological substantiation of operational 
intervalometry should be considered in more detail.

The interest in this method is undoubtedly increasing; not by chance. Proposing the use of intervalometry when conducting tests with loads of a specific nature, it is recommended to record the test results not only by the number of full throwing cycles, but also by their duration (Karpman V.L., 1980 et al.) With subsequent recalculation for the number of repetitions in 1 minute (15 or 30 seconds) according to the formula: for loads of maximum power -

$$
\begin{aligned}
\mathbf{N}(15 ”) & =\frac{15 \cdot \mathbf{n}}{\mathbf{T}^{\prime \prime}{ }_{\mathbf{n}}} \\
\text { or } & \mathbf{N}(\mathbf{3 0} ")=\frac{30 \cdot \mathbf{n}}{\mathbf{T}^{\prime \prime}} ;
\end{aligned}
$$

sub-maximum power loads

$$
\mathrm{N}(60 ")=\frac{60 \cdot \mathrm{n}}{\mathrm{T}^{\prime \prime}},
$$

where: $\mathbf{N}(\mathbf{1 5} "), \mathbf{N}(\mathbf{3 0} "), \mathbf{N}(\mathbf{6 0} ")$ - test result;

n - number of full throwing cycles;

$\mathbf{T}_{\mathbf{n}}$ - interval - duration of full throwing cycles.

Our studies show how equivalent these methods are and which of them deserves more preference.

From the point of view of simplicity and practical convenience, intervalometry is inferior to impulse measurement, although it does not require visual control of the stopwatch hand or the chronometer display dial, but implies the obligatory use of two chronometers, if, in addition to the duration of testing, the total number of repetitions of full throwing cycles, other indicators are simultaneously recorded (for example, the duration of each individual shot cycle with the chronometer always on). In addition, the presence of an auxiliary table, where the data on the recalculation of intervals for the number of throwing cycles per minute are precalculated with an accuracy of 0.01 cycles per minute according to the formula given above, greatly facilitates the work of the researcher [9, $10,11]$.

Being simpler and most importantly familiar, the impulse metering method still remains the main one in practice. Its lower accuracy, which was indicated above, satisfies some researchers (especially if the counting is carried out over a series of consecutive 30- or 60 -second intervals), while others are simply overlooked.

Where selective single counts are carried out, for example, when conducting a test with natural physical exertion of a specific nature, the expediency of switching from impulse metering to intervalometry is clearly evident (Table 1).

Higher accuracy of intervalometry is determined by both objective (from the point of view of the measurement principle) and subjective (from the point of view of the researcher's error) factors.

The range of recorded results from 4 to 23 throws depending on the weight category - in the range from 46 to $130 \mathrm{~kg}$. When using the usual method of determining test results, the indicator has 8 discrete values. This does not take into account the fact that almost always coaches and researchers take into account not only fully completed throwing cycles, but also incomplete ones. In this case, even an incompletely completed cycle was recorded as completed, which significantly distorted the final result.

On the other hand, testing ended when the athlete had enough time ( 1 - 2 seconds) and he could still complete some part of the throwing cycle. As a rule, as the throws are made, the degree of fatigue of the wrestler increases and, as a consequence, the speed of the throwing cycles to the final part of testing decreases from $5-7$ to $25-28 \%$, depending on the throwing technique, weight category, sports qualification, and also the level of physical and functional fitness of an athlete. Moreover, the 
range of indicators can cover the range from 810 to $15-17 \%$. And, if we take into account the work performed (or not performed) by the athlete during one throwing cycle, the difference is only 0.1 of the throwing cycle, depending on the style of wrestling and the technique of performing the throws, it can range from 14.5 to $22.5 \mathrm{~kg} / \mathrm{min}$. At the same time, the use of intervalometry allows only fully completed throwing cycles to be taken into account, even if they took a little more than 30 or 60 seconds.

The point is that as fatigue increases, the duration of the throwing cycles steadily increases to such an extent that sometimes the final throwing cycle in time can be 1.5 times longer than the average indicator recorded for this athlete in the current testing.

Table 1. Comparative analysis of the number of discrete values (range 4 - 28 throw cycles) using two test methods

\begin{tabular}{|c|c|c|c|}
\hline Test time & 15 sec. & 30 sec. & 60 sec. \\
\hline \multicolumn{4}{|c|}{ Impulsometry } \\
\hline (number of DV) & $4-5$ & $8-11$ & $16-28$ \\
\hline \multicolumn{4}{|c|}{ Intervalometry } \\
\hline $\begin{array}{c}\text { pace 0,1 sec } \\
\text { pumber of DV) }\end{array}$ & 32 & 58 & 126 \\
\hline (number of DV) & 66 & 114 & 252 \\
\hline
\end{tabular}

dv

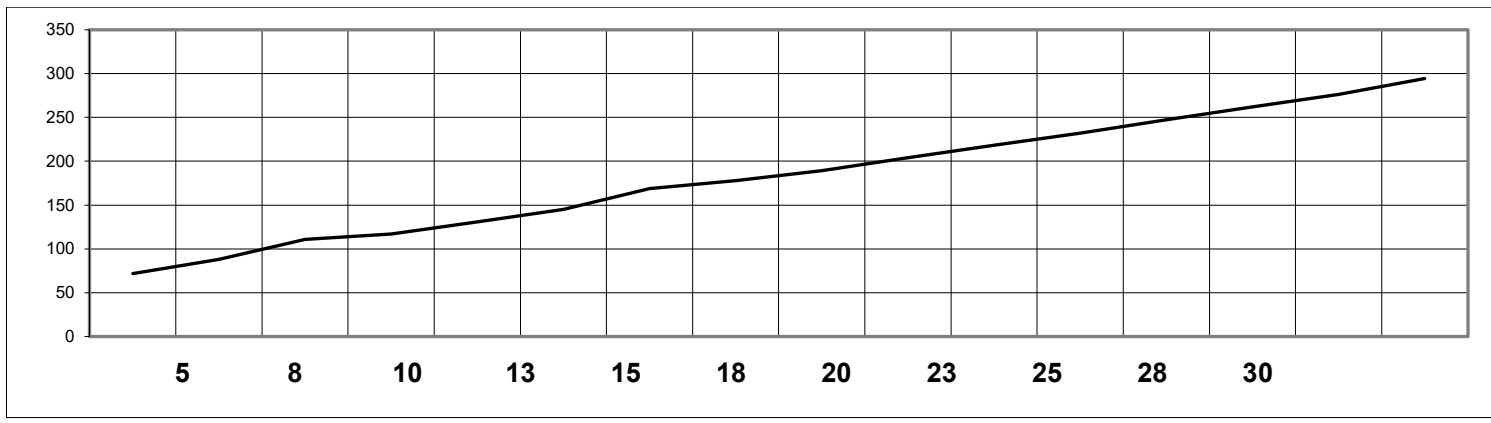

Legend: DV - number of discrete values; $1,2,3,4,5 \ldots-$ number of recorded full throwing cycles.

\section{Fig. 1. Dependence of the number of discrete values (vertical axis) on the number of recorded} full throwing cycles (horizontal axis)

The objective advantages of using intervalometry are related to two points.

First, this measurement method has a higher resolution. The scale contains a larger number of discrete values (DV), covering indicators in the range from 5 to 30 throwing cycles, when the total duration of one throwing cycle can be from 2.5 to 4.5 seconds, which with a chronometer "step" of 0.1 seconds, in the named range, makes it possible to measure 152 discrete values (Table 2). Meanwhile, with impulse metering, the scale has measurement 1 throw cycle limit per counting period i.e. in the range from 6 to 30 throwing cycles per minute, 
and the number of discrete values will be equal to 28 . With respect to the measured value (full throwing cycles), with an increase in its current values, the accuracy of the results obtained by the two compared methods changes in opposite directions.

With impulse measurement, it rises: the measurement interval of $2.5-4.5$ seconds is $2.5-5 \%$ of the measured value when throwing cycles are performed. With intervalometry, with its constant for the entire scale, the accuracy of time measurement $(0.1 \mathrm{sec}$. Or 0.05 sec. - when using an electronic stopwatch), the relative accuracy of the scale divisions decreases with a shortening of the throwing cycles. In the case of determining the duration of 10 throw cycles, the scale division value is, respectively, 0.67 of the throw cycle $1.4 \%$ of the measured value. Thus, even with the most favorable for impulse metering and the most unfavorable for intervalometry zone, the resolution of the compared methods approaches: with impulse metering during the testing time of $60 \mathrm{sec}$, the scale has 28 discrete values, and with intervalometry for the same $60 \mathrm{sec}-152$ discrete values. At the same time, it is important to take into account the fact that in the latter case, the total throwing cycles are counted, each of which is performed in a very short period of time - from 2.5 to 3 seconds. If you measure here the total time of 20 cycles, i.e. take a comparable measurement time (duration of one cycle from 2.5 to $4.5 \mathrm{sec}$.), then the resolution of intervalometry increases significantly. Secondly, intervalometry, by its very principle, gives a smaller measurement error. It allows you to take into account a certain number of full throwing cycles, while during impulse measurement during the measurement period ( 30 or 60 seconds), the "unfulfilled" shares of the last of the registered throwing cycles fall, that is, the final result is overestimated.
So, with pulse metering, the result of 10 cycles in 30 seconds can be shown. not only with the total duration of 10 cycles in the first case from 27.55 to 30.0 seconds, the 10th cycle is added to 9 complete cycles, "not supported" by the corresponding time interval. In this case, the error of the test results can be from 155 to $225 \mathrm{kgm} / \mathrm{min}$. In other words, pulse metering includes an organic error of \pm 0.9 cycles over a measurement time period of 27.55 or 30.0 seconds.

Intervalometry is devoided of such an error, which in the case of impulse measurement, even with instrumental recording of throwing cycles, can take two sample intervals in the range of 3.5 seconds. show the difference in 35 discrete values where the indicators are exactly the same, and will not reveal the difference between two results that differ from each other in the range from 125 - $220 \mathrm{kgm}$. (Figure 2).

When considering the subjective factor, i.e. the error, depending on the researcher (Table 2). It should be noted that its maximum value for an experienced researcher with impulse measurements is no more than 1 shot per measurement period, and for intervalometry no more than $\pm 0.1 \mathrm{sec} .( \pm 0.05$ sec.) During the countdown (corresponding to the spread of the latent period of the sensorimotor reaction to the rhythmic stimulus).

Thus, the subjective error, in principle equal to the resolvability of the methods, is much less in the case of intervalometry. If, when registering the result, the researcher makes an error of just one throw (one full throwing cycle), then when calculating the indicators for 15 seconds, the discrepancy with the true result will be $20 \%$, for 30 seconds $10 \%$, for 60 seconds - $6.67 \%$, and when calculating indicators using intervalometry for 15 seconds - only $5 \%$, for 30 seconds $-3.2 \%$, and for 60 seconds $-1.5 \%$ (Table 2, Figure 3). 
Table 2. Comparative characteristics of determining the number of throwing cycles by the method of intervalometry using an electronic chronometer (pace $0.1 \mathrm{sec}$ and pace $0.05 \mathrm{sec}$ )

\begin{tabular}{|c|c|c|c|c|c|c|c|}
\hline \multirow{2}{*}{ № } & \multirow{2}{*}{ 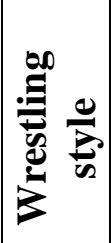 } & \multirow{2}{*}{$\begin{array}{l}\text { Weight } \\
\text { category }\end{array}$} & \multirow{2}{*}{$\begin{array}{l}\text { number DV } \\
\text { T" } 60,0-65,0 \\
\text { pace - } \mathbf{0 , 1} \mathbf{~ s e c}\end{array}$} & \multirow{2}{*}{$\begin{array}{c}\text { number DV } \\
\text { T" 60,0-65,0 } \\
\text { pace - } \mathbf{0 , 0 5} \mathbf{~ s e c}\end{array}$} & \multirow{2}{*}{$\begin{array}{c}\text { Work } \\
\text { when performing } \\
\text { one throw cycle } \\
(\mathrm{kgm})\end{array}$} & \multicolumn{2}{|c|}{$\begin{array}{l}\text { probable } \\
\text { mistake }\end{array}$} \\
\hline & & & & & & \pm & $\%$ \\
\hline 1. & \multirow{7}{*}{$\stackrel{0}{\frac{0}{3}}$} & $<60$ & $32-46$ & $66-72$ & $157,2-161,0$ & 1,90 & 1,21 \\
\hline 2. & & $60-66$ & $46-58$ & $72-80$ & $161,0-171,6$ & 5,30 & 3,29 \\
\hline 3. & & $66-73$ & $58-64$ & $80-112$ & $171,6-186,1$ & 7,25 & 4,22 \\
\hline 4. & & $73-81$ & $64-80$ & $112-142$ & $186,1-196,7$ & 5,30 & 2,85 \\
\hline 5. & & $81-90$ & $80-92$ & $142-178$ & $196,7-212,4$ & 7,85 & 3,99 \\
\hline 6. & & $90-100$ & $92-112$ & $178-228$ & $212,4-227,2$ & 7,40 & 3,48 \\
\hline 7. & & $>100$ & $112-126$ & 228 - 252 & $227,2-234,5$ & 3,65 & 1,61 \\
\hline 1. & \multirow{9}{*}{ 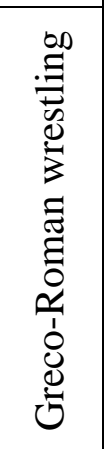 } & $<59$ & $26-40$ & $64-70$ & $137,7-140,2$ & 1,25 & $\mathbf{0 , 9 1}$ \\
\hline 2. & & $59,1-66$ & $32-48$ & $70-80$ & $140,2-149,7$ & 4,75 & 3,39 \\
\hline 3. & & $66,1-71$ & $48-62$ & $80-118$ & $149,7-160,7$ & 5,50 & 3,67 \\
\hline 4. & & $71,1-75$ & $62-76$ & $118-138$ & $160,7-163,8$ & 1,55 & 0,96 \\
\hline 5. & & $75,1-80$ & $76-84$ & $138-152$ & $163,8-166,5$ & 1,35 & $\mathbf{0 , 8 2}$ \\
\hline 6. & & $80,1-85$ & $84-92$ & $152-172$ & $166,5-176,2$ & 4,85 & 2,91 \\
\hline 7. & & $85,1-98$ & $92-100$ & $172-194$ & $176,2-187,2$ & 5,50 & 3,12 \\
\hline 8. & & $98-130$ & $100-114$ & $194-210$ & $187,2-222,2$ & 17,50 & $\mathbf{9 , 3 5}$ \\
\hline 9. & & $>130$ & $112-122$ & $210-244$ & $222,2-229,3$ & 3,55 & 1,60 \\
\hline 1. & \multirow{9}{*}{ 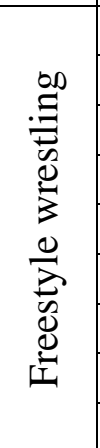 } & $<57$ & $30-42$ & $62-70$ & $136,9-139,9$ & 1,50 & 1,10 \\
\hline 2. & & $57-61$ & $42-58$ & $70-82$ & $139,9-143,2$ & 1,65 & 1,18 \\
\hline 3. & & $61-65$ & $58-70$ & $82-110$ & $143,2-153,5$ & 5,15 & 3,60 \\
\hline 4. & & $65-70$ & $70-82$ & $110-138$ & $153,5-158,9$ & 2,70 & 1,76 \\
\hline 5. & & $70-74$ & $82-90$ & $138-150$ & $158,9-162,2$ & 1,65 & 1,04 \\
\hline 6. & & $74-86$ & $90-96$ & $150-174$ & $162,2-179,3$ & 8,55 & 5,27 \\
\hline 7. & & $86-97$ & $96-106$ & $174-192$ & $179,3-189,9$ & 5,30 & 2,96 \\
\hline 8. & & $97-125$ & $106-114$ & $192-212$ & $189,9-219,6$ & 14,85 & 7,82 \\
\hline 9. & & $>125$ & $116-124$ & $212-248$ & $219,6-222,6$ & 1,50 & $\mathbf{0 , 6 8}$ \\
\hline 1. & \multirow{9}{*}{$\begin{array}{l}\text { \& } \\
\text { है } \\
\text { ज्ञ }\end{array}$} & $<52$ & $34-48$ & $68-82$ & $121,2-123,6$ & 1,20 & 0,99 \\
\hline 2. & & $52-57$ & $48-60$ & $82-100$ & $123,6-131,8$ & 4,10 & 3,32 \\
\hline 3. & & $57-62$ & $60-74$ & $100-126$ & $131,8-138,8$ & 3,50 & 2,66 \\
\hline 4. & & $62-68$ & $74-82$ & $126-148$ & $138,8-144,8$ & 3,00 & 2,16 \\
\hline 5. & & $68-74$ & $82-90$ & $148-164$ & $144,8-150,8$ & 3,00 & 2,07 \\
\hline 6. & & $74-80$ & $90-96$ & $164-192$ & $150,8-161,2$ & 5,20 & 3,45 \\
\hline 7. & & $80-90$ & $96-106$ & $192-214$ & $161,2-168,4$ & 3,60 & 2,23 \\
\hline 8. & & $90-100$ & $106-114$ & $214-232$ & $168,4-178,8$ & 5,20 & 3,09 \\
\hline 9. & & $>100$ & $114-128$ & $232-256$ & $178,8-182,2$ & 1,70 & $\mathbf{0 , 9 5}$ \\
\hline
\end{tabular}

Note. The following designations are adopted in the table: $\mathrm{n}$ - the number of full throwing cycles; $\mathrm{T}$ "60 - duration of the procedure; DV - discrete valuee. 


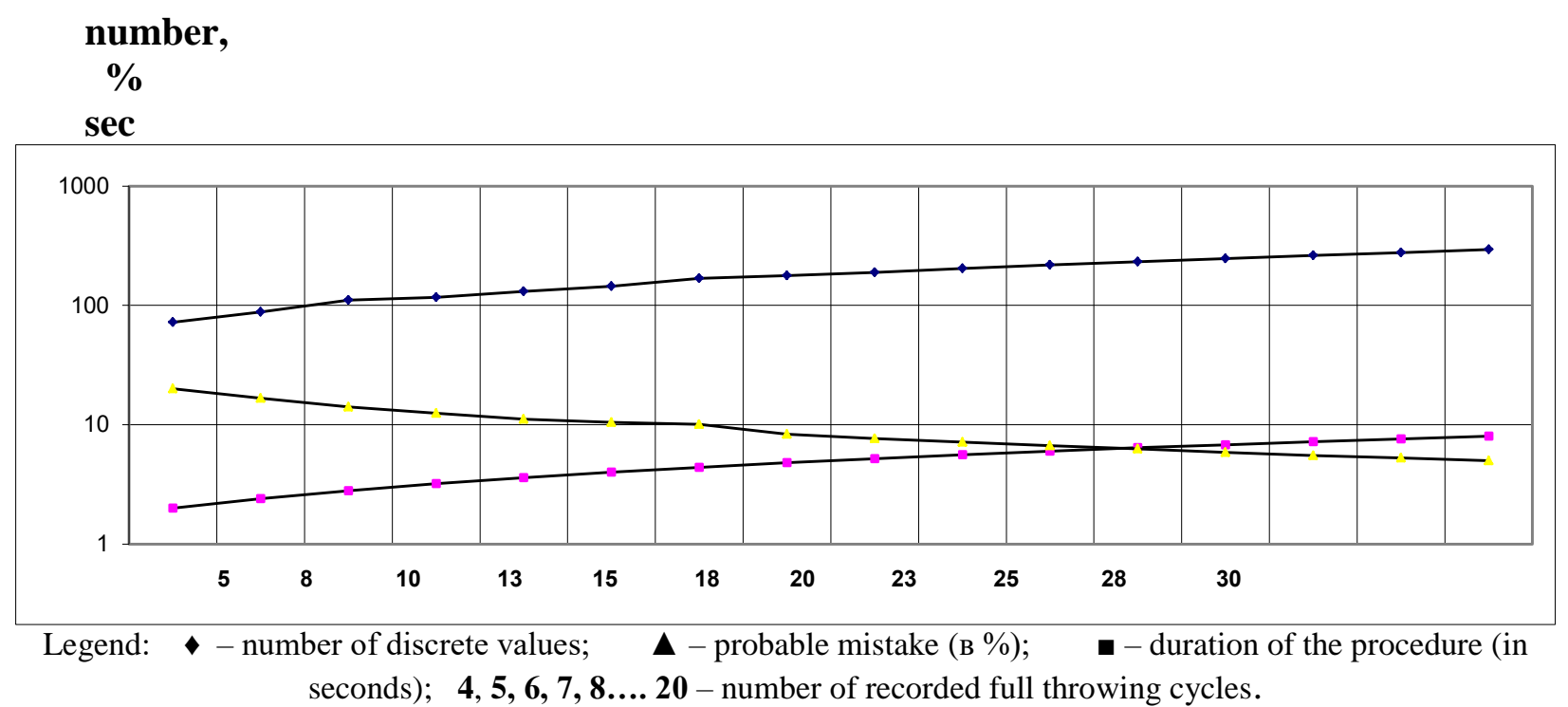

\section{Fig. 3. Dependence of the information content (duration, number of discrete values and accuracy) of the procedure for determining the results by the intervalometry method on the number of recorded (from 5 to 30) throwing cycles (the scale of the diagram is logarithmic)}

The probability of the maximum magnitude of the error here is further reduced due to the fact that: first, the time shifts between the initial beat of the pulse and the start of the stopwatch, and between the last beat and the deactivation of the stopwatch, for each individual are, in principle, unidirectional; and secondly, timing with a fixed stopwatch hand has less chance of error than observing a moving hand in the case of pulse metering, for example, pulse metering can show 10 throwing cycles in 30 seconds. not only with a rhythm of $0.33 \mathrm{bps} / \mathrm{sec}$, but also with a rhythm of 0.37 to $0.42 \mathrm{bps} / \mathrm{sec}$., i.e. with a total duration of 10 cycles from 27.5 to 30 seconds, in the first case, the 10th cycle is added to 9 full cycles, not "reinforced" by the corresponding interval, in the second - to 10 full throwing cycles, 0.9 interval is added without a corresponding throw, which remains "overboard" of the measurement segment for 30 or 60 seconds.

Thus, the subjective error, in principle equal to the resolvability of the methods, is much less in the case of intervalometry. This is due to the fact that: firstly, the time shifts at the beginning of testing between the "Start!" and turning on the stopwatch, and between the command "Stop!" and switching off the stopwatch at the end of the last throwing cycle for each individual are, in principle, unidirectional; and secondly, timing with a fixed stopwatch hand contains less possibility of error than when observing a moving hand in the case of impulse metering (Table 2, Figure $3)$.

Conclusions. Summarizing all of the above, we can conclude that intervalometry is more than an order of magnitude superior to impulse measurement in accuracy and can become the main way to quickly assess the results of testing the level of special physical and functional training of wrestlers at various stages of training.

To reduce the significant time spent on recalculations, we have developed special tables for determining the number of throwing cycles by the method of intervalometry in the range from 5 to 30 throwing cycles with high resolution (accuracy is up to 0.1 throwing cycle), which are very simple in circulation and allow trainers and researchers to significantly reduce the time for processing test results and get more accurate data. 


\section{References:}

1. Dorgan V., Mrut I., Postolachi A. (2018). Loads of a Specific Nature and their Impact on the Organism of Femele Judo Partitioners. In: The impact of Sport and Phisical Education Sciense on Todays Society. Iasi, p. 59-67.

2. Manolachi Veaceslav (2003). Sporturi de luptă - teorie şi metodică: (Luptele libere, grecoromane, judo). Chişinău: INEFS. 400 p.

3. Геселевич В.А. (1973). Методы оценки физической работоспособности бориов. В: Спортивная борьба. М.: Физкультура и Спорт, с.47-48.

4. Замятин Ю.П., Тараканов Б.И. (1985). Экспериментальное обоснование методики педагогического контроля физической подготовленности борцов. В: Пути повышения эффективности подготовки юных и взрослых спортсменов: Сб. науч. тр. Л.: ГДОИФК, с.2226.

5. Каплин В.Н., Еганов А.В., Сиротин О.А. (1990). Оиенка уровня спещииальной и общефизической подготовленности дзюдоистов - юниоров: Методич. рекомендации. М.: Госкомспорт СССР. 22 с.

6. Карпман В.Л., Белоцерковский З.Б., Гудков И.А. (1984). Тестирование в спортивной медииине. М.: ФиС, с. 135 - 194.

7. Спортивная физиология (1986). Учеб. Для ин-тов физ.культ. Под ред. Я.М. Коца. М.:ФиС. 240 с.

8. Манолаки В.Г. (1989). Экспериментальное обоснование информативности тестов для контроля за подготовкой квалифицированных дзюдоисток. В: Становление и совершенствование тактико-технического мастерства в спортивной борьбе: Сб. науч. тр. Омск: ОГИФК, с.79-84.

9. Манолаки В., Мруц И. (2017). Определение относительных показателей физической работоспобности бориов с применением специфических нагрузок. B: Materiale Congresului Ştiinţific Internaţional „Sport. Olimpism. Sănătate”: culegere de rezumate, ed. 2, 26-28 octombrie 2017. Chişinău: USEFS, p.117.

10. Манолаки В.В., Мруц И.Д., Манолаки В.Г. (2019). Относительные показатели физической работоспособности бориов вольного стиля $P W C_{170}(V) u$ применение специфических нагрузок. Монография. Кишинэу: Editura USEFS. 346 с.

11. Мруц И.Д. (2006). Сборник таблич для определения пульса методом интервалометрии. Кишинев: ГУФВиС. 28 с.

12. Нагинская С.В. (1987). Основы спортивной метрологии. Киев: Высшая школа. 152 с.

13. Sjostrad T. (1947). Changes in the Respiratory organs of workmen at one ores melding work. Acta Med. Scand., Suppl. 196, p. 687 - 699. 